九州大学学術情報リポジトリ

Kyushu University Institutional Repository

\title{
Inheritance of Bulb Dormancy and Early Flowering Ability in F_1 Progenies of Intra- and Interspecific Crosses of Lilium formosanum and L. Longiflorum
}

Mojtahedi, Narges

Laboratory of Horticultural Science, Division of Agronomy and Environmental Sciences, Department of Agro-environmental Sciences, Faculty of Agriculture, Kyushu University

Hiramatsu, Michikazu

Laboratory of Horticultural Science, Division of Agronomy and Environmental Sciences, Department of Agro-environmental Sciences, Faculty of Agriculture, Kyushu University

Mizunoe, Yuki

Laboratory of Horticultural Science, Division of Agronomy and Environmental Sciences, Department of Agro-environmental Sciences, Faculty of Agriculture, Kyushu University

Okubo, Hiroshi

Laboratory of Horticultural Science, Division of Agronomy and Environmental Sciences, Department of Agro-environmental Sciences, Faculty of Agriculture, Kyushu University

https://doi.org/10.5109/26156

出版情報: 九州大学大学院農学研究院紀要. 58 (1)，pp.23-25，2013-02. Faculty of Agriculture， Kyushu University

バージョン :

権利関係: 


\title{
Inheritance of Bulb Dormancy and Early Flowering Ability in $F_{1}$ Progenies of Intra- and Interspecific Crosses of Lilium formosanum and L. longiflorum
}

\author{
Narges MOJTAHEDI ${ }^{1 *}$, Michikazu HIRAMATSU, Yuki MIZUNOE ${ }^{1}$ \\ and Hiroshi OKUBO
}

\author{
Laboratory of Horticultural Science, Division of Agronomy and Environmental Sciences, \\ Department of Agro-environmental Sciences, Faculty of Agriculture, \\ Kyushu University, Fukuoka 812-8581, Japan \\ (Received October 18, 2012 and accepted November 8, 2012)
}

\begin{abstract}
One-year-old seedlings of the northern populations of Lilium longiflorum in the Ryukyu Archipelago have deep dormancy in summer, whereas those of the southern populations of $L$. longiflorum and $L$. formosanum show lack or reduction of dormancy. Dormancy status of the $\mathrm{F}_{1}$ progenies of intraspecific hybrids among $L$. longiflorum with different degrees of dormancy and interspecific hybrids between $L$. formosanum and L. longiflorum was studied in an open field condition. Three populations of L. longiflorum, Yakushima (LYA) and Kikai Jima (LKI) in the Ryukyu Archipelago, Japan and Pitouchiao (LPI), Taiwan and two populations of L. formosanum, Wulai (FWU), Taiwan and Fukuoka (FFU), Japan were used. FFU, FWU, LPI and hybrids of FFU $\times$ FWU, FFU $\times$ LPI and FWU $\times$ LPI continued developing leaves in summer and flowered in a year after seed sowing, while LYA and LKI and the hybrids with them did not. Since FFU, FWU and LPI are categorized as non-dormant populations and LKI and LYA as deep dormant, the bulb dormancy seems to be dominant, while early flowering ability is recessive in the $\mathrm{F}_{1}$ progenies.
\end{abstract}

Key words: dormancy, inheritance, Lilium formosanum, Lilium longiflorum

\section{INTRODUCTION}

Lilium longiflorum and its derivative, L. formosanum (Hiramatsu et al., 2001) are among Liliaceae endemic to the subtropical Ryukyu Archipelago, Japan and Taiwan (Wilson, 1925; McRae, 1998). We previously confirmed that temperature is the important factor for differentiation in degree of dormancy in the one year old seedlings of L. longiflorum populations through the geographic gradient of the Ryukyu Archipelago (Mojtahedi et al., 2011, 2012). In those experiments, dormancy in the one year old seedlings of northern populations of $L$. longiflorum was induced by high summer temperature wherein those populations stopped leaf development when the temperature reached to $25^{\circ} \mathrm{C}$ in the middle of June and showed deep dormant status till the end of following January without producing any leaf and flower, while those of L. formosanum and L. longiflorum populations growing in the southern part of the Archipelago showed no or weak dormancy even in high temperature $\left(25\right.$ and $\left.30^{\circ} \mathrm{C}\right)$ in July and August, and can produce flowers in the first year (Mojtahedi et al., 2011, 2012).

Inheritance of dormancy and/or bulb formation has been reported only in a few species (Tashiro, 1984; Tashiro et al., 1995; Xiao et al., 2010), due to the difficulties of obtaining dormant and non-dormant phenotypes in the same species or fertile progenies between them. Induction of early-flowering traits has been

\footnotetext{
1 Laboratory of Horticultural Science, Division of Agronomy and Environmental Sciences, Department of Agro-environmental Sciences, Faculty of Agriculture, Kyushu University, Fukuoka 812-8581, Japan

* Corresponding author (E-mail: narmojtahedi@gmail.com)
}

achieved in many horticultural crops. In Lilium breeding, early flowering cultivars have been developed by the crosses of $L$. formosanum with $L$. longiflorum $(=L . \times$ formolongi).

In this study, inheritance of dormancy and early flowering traits of $\mathrm{F}_{1}$ progenies of intraspecific hybrids between dormant and non-dormant types of $L$. longiflorum and interspecific hybrids between $L$. formosanum and $L$. longiflorum populations were investigated.

\section{MATERIALS AND METHODS}

\section{Plant materials and culture}

Three populations of $L$. longiflorum, Yakushima (LYA) and Kikai Jima (LKI) in the Ryukyu Archipelago, Japan and Pitouchiao (LPI), Taiwan and two populations of L. formosanum, a Wulai (FWU) population in Taiwan and a domesticated population in Fukuoka (FFU), Japan were used.

All the seeds were sown in November 2009 or 2010 in cell trays containing the mixture of sohagnum peat moss: vermiculite (Redi- Earth Sun Gro Horticulture Distribution Inc., U.S.A.), and grown in incubators (16/8 h photoperiod, $70 \%$ humidity, $15^{\circ} \mathrm{C}$ ) for 5 months. They were transplanted in the following May to the plastic pots containing red loam: commercial soil (4:1) to grow in an open field. Nitrogen was used as a fertilizer in the soil mixture with the ratio of $\left(15 \mathrm{~g} / 10000 \mathrm{~cm}^{2}\right)$ and leaf mold was used after transplantation to prevent the soil evaporation.

\section{Hybridization method and culture of $\mathrm{F} 1$ progenies}

The inter- and intra-specific cross hybridization started immediately after flowering. Flowers of female plants (FFU, FWU, LPI and LKI) were emasculated 2 
days before anthesis. Anthers were kept in dry condition at room temperature to produce mature pollen grains after harvest and used during 7 days after emasculation to conduct intraspecific cross hybridization from end of May to end of June. Mature pollen grains were kept in $-20^{\circ} \mathrm{C}$ to carry out interspecific cross hybridization from middle of July to mid-October. Pollination was carried out 2 days after anthesis and mature capsules were harvested 2 months after pollination. Seeds were dried for one month at $25^{\circ} \mathrm{C}$.

The seeds of the $F_{1}$ progenies were cultured in November 2010 and 2011 using the same mentioned methods. Scaly leaf morphology was checked to confirm seedlings hybridity. Weekly leaf number and early flowering ability in the first year of at least 10 individuals were measured for all populations.

\section{RESULTS AND DISCUSSION}

Total leaf numbers of the parents were larger in FFW, FFU and LPI (non-dormant populations) than in
LKI and LYA (dormant populations), and the former three populations showed an early flowering ability (Table 1) in accordance with our previous reports (Mojtahedi et al., 2011, 2012). Hybrids of FFU $\times$ FWU, FFU $\times$ LPI and FWU $\times$ LPI continued leaf development in the summer, while the other hybrids did not (Fig. 1). $\mathrm{FFU} \times \mathrm{FWU}, \mathrm{FFU} \times$ LPI and FWU $\times$ LPI developed 24-25 leaves and some of them flowered in less than 300 days after seed sowing, while the other hybrids produced only 3-5 leaves and did not flower in a year (Table 2). It is clearly shown that the $\mathrm{F}_{1}$ progenies of dormant $\times$ non-dormant type and its reciprocal nondormant $\times$ dormant type populations are dormant type. It can be concluded that dormancy is dominant over non-dormancy in L. longiflorum and L. formosanum.

Allium $\times$ wakegi, a natural interspecific hybrid between Welsh onion (A. fistulosum, non-bulbous species) as a maternal plant and shallot (A. cepa aggregetum group, bulbous species) as a paternal plant, forms bulbs and has dormancy (Tashiro, 1984; Hizume, 1994; Tashiro et al., 1995). The hybrids of the reciprocal

Table 1. Total leaf number and flowering performance of L. formosanum and L. longiflorum in different populations in the first year growth

\begin{tabular}{|c|c|c|c|c|}
\hline \multirow[b]{2}{*}{ Population $^{2}$} & \multirow{2}{*}{$\begin{array}{l}\text { Total leaf } \\
\text { number }^{y}\end{array}$} & \multirow[b]{2}{*}{$\begin{array}{l}\% \text { of first year } \\
\text { flowering }^{\mathrm{x}}\end{array}$} & \multicolumn{2}{|c|}{ Days to first flowering after } \\
\hline & & & $\begin{array}{l}\text { seed sowing } \\
(\min -\max )\end{array}$ & $\begin{array}{l}\text { transplantation } \\
\quad(\min -\max )\end{array}$ \\
\hline FFW & $37.6 \pm 4.0$ & 65 & 280 (265-295) & $110(95-125)$ \\
\hline FFU & $54.1 \pm 2.4$ & 90 & $332(300-365)$ & $162(130-195)$ \\
\hline LPI & $24.5 \pm 3.3$ & 19.7 & $260(240-280)$ & $90(70-110)$ \\
\hline LKI & $5.5 \pm 0.3$ & 0 & $452(445-460)$ & $282(275-290)$ \\
\hline LYA & $4.1 \pm 0.1$ & 0 & $450(440-460)$ & 282 (270-295) \\
\hline
\end{tabular}

${ }^{z}$ FFW, FFU, LPI, LKI and LYA; see text

${ }^{y}$ Total leaf number in the first year growth \pm SE

${ }^{x}$ (Number of flowered plants/Number of total plants) $\times 100$

Table 2. Total leaf number and flowering performance of $F_{1}$ progenies in the first year growth

\begin{tabular}{|c|c|c|c|c|}
\hline \multirow[b]{2}{*}{$\begin{array}{c}\text { Cross } \\
\text { combination }^{2}\end{array}$} & \multirow[b]{2}{*}{$\begin{array}{l}\text { Total leaf } \\
\text { number }\end{array}$} & \multirow[b]{2}{*}{$\begin{array}{c}\% \text { of first year } \\
\text { flowering }\end{array}$} & \multicolumn{2}{|c|}{ Days to first flowering after } \\
\hline & & & $\begin{array}{l}\text { seed sowing } \\
\text { (min-max) }\end{array}$ & $\begin{array}{l}\text { transplantation } \\
\quad(\min -\max )\end{array}$ \\
\hline FFU×FWU & $25.2 \pm 3.5$ & 20 & $292(285-300)$ & $122(115-130)$ \\
\hline FFU×LPI & $25.3 \pm 3.4$ & 14 & $297(285-310)$ & $162(150-175)$ \\
\hline FFU×LKI & $4.1 \pm 0.1$ & 0 & $-{ }^{\mathrm{w}}$ & - \\
\hline FFU $\times L Y A$ & $3.3 \pm 0.1$ & 0 & - & - \\
\hline FWU×LPI & $24.0 \pm 2.4$ & 55 & $282(255-310)$ & $147(120-175)$ \\
\hline FWU×LKI & $3.9 \pm 0.2$ & 0 & - & - \\
\hline FWUXLYA & $4.6 \pm 0.1$ & 0 & - & - \\
\hline LPI $\times L K I$ & $3.1 \pm 0.1$ & 0 & - & - \\
\hline LPI $\times L Y A$ & $3.0 \pm 0.0$ & 0 & - & - \\
\hline LKI×LPI & $3.4 \pm 0.1$ & 0 & - & - \\
\hline
\end{tabular}

${ }^{z}$ FFW, FFU, LPI, LKI and LYA; see text

y Total leaf number in the first year growth \pm SE

x (Number of flowered plants/Number of total plants $) \times 100$

${ }^{\text {w }}$ Not flowered until now 


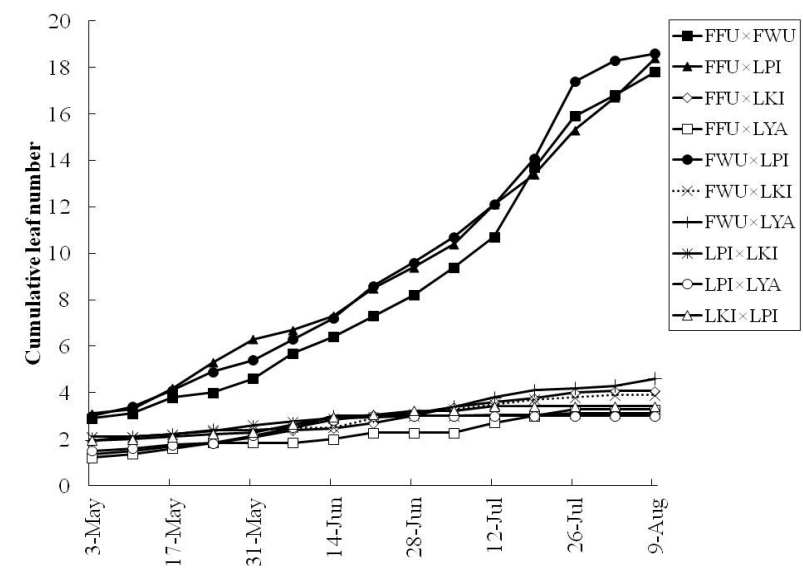

Fig. 1. Growth patterns of $\mathrm{F}_{1}$ hybrids of interspecific cross hybridization between $L$. formosanum (FFU, FWU) and $L$. longiflorum or intraspecific cross hybridization between dormant (LKI, LYA) and non-dormant (LPI) type of $L$. longiflorum populations. FFW, FFU, LPI, LKI and LYA; see text.

crossings also form bulbs (Arifin et al., 2000) in agreement with our results. On the other hand, bulb formation in the $\mathrm{F}_{1}$ progenies of non-dormant type chives (Allium schoenoprasum) $\times$ dormant type A. schoenoprasum var. foliosum was not observed, indicating the trait is recessive (Xiao et al., 2010). Dormancy trait in bulbous plants may be species dependent.

Early flowering ability was not inherited in the progenies when at least one parent is a dormant type in our study. It is in contradiction to the fact that the cultivars of Lilium $\times$ formolog $i$ with early flowering ability were developed by the crosses of $L$. formosanum $\times L$. longiflorum (Beattie and White, 1993; Shimizu, 1971), although it is unknown whether L. longiflorum with early flowering ability was used in their breeding. It was also reported that the early flowering ability of $L$. formosanum as female parent in its hybrids with $L$. auratum, L. speciosum, L. regale as male parents is dominant (Saruwatari, 2009). Hai et al. (2012) introduced the hybrids of $L$. formolongi with $L$. brownii var. colchestri that flowered within their first year growth.

It is reported that threshold plant size (Hiramatsu et al., 2012) and development of adequate scaly leaves during the first six months of their vegetative growth is one of the obligatory requirements to move into reproductive phase in L. longiflorum and L. formosanum (Mojtahedi et al., 2012). The leaf number of all the $\mathrm{F}_{1}$ progenies did not reach to the minimum threshold number of leaves to start the reproductive phase. Low degrees of flowering rate and little net production during spring to summer in the first year in northern $L$. longiflorum populations (Hiramatsu et al., 2002) associated with quiescence in leaf development during summer set off the theory that the early flowering ability is adaptive strategy to grow without dormancy throughout the year (Mojtahedi et al., 2012). Whenever the dormancy trait is expressed, it causes less leaf develop- ment that makes little net production and the early flowering ability would be suppressed. Our results proved this theory in the $\mathrm{F}_{1}$ progenies. In conclusion, deep bulb dormancy in the $\mathrm{F}_{1}$ progenies of the Lilium populations studied is dominant, while early flowering ability is recessive.

\section{REFERENCES}

Arifin, N. S., Y. Ozaki and H. Okubo 2000 Genetic diversity in Indonesian shallot (Allium cepa var. ascalonicum) and Allium $\times$ wakegi revealed by RAPD markers and origin of $A$. $\times$ wakegi identified by RFLP analyses of amplified chloroplast genes. Euphytica, 111: 23-31

Beattie, D. J. and J. W. White 1993 Lilium - hybrids and species. In "The Physiology of Flower Bulbs", ed. by A. De Hertogh and M. Le Nard, Elsevier Science Publ., Amsterdam, pp. 423-545

Hai, N. T. L., M. Hiramatsu, J.-H. Kim, J. Masuda and H. Okubo 2012 Interspecific hybrids production between Lilium brownii var. colchesteri and its close relatives by ovary slice culture. J. Japan. Soc. Hort. Sci., 81: 191-197

Hiramatsu, M., K. Ii, H. Okubo, K. L. Huang and C. W. Huang 2001 Biogeography and origin of Lilium longiflorum and Lilium formosanum (Liliaceae) in the Ryukyu Archipelago and Taiwan as determined by allozyme diversity. Amer. J. Bot., 88: $1230-1239$

Hiramatsu, M., H. Okubo, K. Yoshimura, K. L. Huang and C. W. Huang 2002 Biogeography and origin of Lilium longiflorum and Lilium formosanum II- Intra- and Interspecific variation in stem leaf morphology, flowering rate and individual net production during the first year seedling growth. Acta Hort., $\mathbf{5 7 0}$ $331-334$

Hiramatsu, M., J. Masuda, S. Sakazono and H. Okubo 2012 Evolution of early flowering ability in Lilium formosanum from its progenitor Lilium longiflorum. Floriculture and Ornamental Biotechnology 6: (In print)

Hizume, M. 1994 Allodiploid nature of Allium wakegi Araki revealed by genomic in situ hybridization and localization of 5S and 18S rDNAs. Jap. J. Genet., 69: 407-415

McRae, E. A. 1998 Lilies, A Guide for Growers and Collectors. Timber Press, Portland, Oregon

Mojtahedi, N., J. Masuda, M. Hiramatsu and H. Okubo 2011 Variation of summer bulb dormancy in Lilium longiflorum and Lilium formosanum populations along latitude of the Ryukyu Archipelago. Hort. Res. (Japan) 10 (Suppl. 2): 544

Mojtahedi, N., J. Masuda, M. Hiramatsu and H. Okubo 2012. Latitudinal variation of bulb dormancy and early flowering ability in Lilium longiflorum and Lilium formosanum populations of the Ryukyu Archipelago and Taiwan. Abstract Book of XI International Symposium on Flower Bulbs and Herbaceous Perennials, p. 48

Saruwatari, H. 2009 Studies on precocious flowering of Lilium formosanum and its introduction into other Lilium species. PhD Thesis, Kyushu University, Japan

Shimizu, M. 1971 Lilies of Japan. Seibundo Shinkosha, Tokyo (In Japanese)

Tashiro, Y. 1984 Genome analysis of Allium $\times$ wakegi Araki. J. Japan. Soc. Hort. Sci., 52: 399-407

Tashiro, Y., T. Oyama, Y. Iwamoto, R. Noda and S. Miyazaki 1995 Identification of maternal and paternal plants of Allium $\times$ wakegi Araki by RFLP analysis of chloroplast DNA. J. Japan. Soc. Hort. Sci., 63: 819-824

Wilson, E. H. 1925 The Lilies of Eastern Asia. Dulau and Company, London

Xiao, J., K. Ureshino, M. Hosoya, H. Okubo and A. Suzuki 2010 Inheritance of bulb formation in Allium schoenoprasum L. J. Japan. Soc. Hort. Sci., 79: 282-286 